\title{
Limited flexibility in resource use in a coral reef grazer foraging on seasonally changing algal communities
}

\author{
Y. Afeworki · J. H. Bruggemann $\cdot$ J. J. Videler
}

Received: 14 June 2010/Accepted: 27 September 2010/Published online: 16 October 2010

(C) The Author(s) 2010. This article is published with open access at Springerlink.com

\begin{abstract}
Feeding ecology of three life phases of the parrotfish Scarus ferrugineus was studied on a southern Red Sea fringing reef by comparing availability and consumption of benthic algae during the monsoon hot and cool seasons. Dominant biota covering dead carbonate substrates were in decreasing order of importance: turfs on endoliths, turfs on crustose corallines, and crustose corallines. On the reef crest and shallow fore reef, composition of the biota changed seasonally. Cover of turfs on endoliths and turfs on crustose corallines was higher during the hot season, while crustose corallines and macroalgae (only on reef crest) increased during the cool season. Biota in the deep fore reef did not show seasonal variation. All life phases used similar resources and showed selective feeding in all zones. Turfs on endoliths, followed by turfs on crustose corallines, was the primary feeding substrate. These two sources represented over $92 \%$ of bites during both seasons. Crustose corallines, macroalgae, and living corals were negligible components being strongly avoided at all zones and seasons. Resource use varied seasonally on the reef crest and shallow fore reef, while it remained
\end{abstract}

Communicated by Ecology Editor Prof. Mark Hay

Y. Afeworki ( $₫) \cdot$ J. J. Videler

Department of Ocean Ecosystems, University of Groningen,

P.O. Box 14, 9750 AA Haren, The Netherlands

e-mail: y.afeworki@rug.nl

Y. Afeworki

Department of Applied Marine Science, College of Marine

Science and Technology, P.O. Box 170, Massawa, Eritrea

J. H. Bruggemann

Laboratoire ECOMAR, Faculté des Sciences et Technologies, Université de La Réunion, 15 Avenue René Cassin, BP 7151, 97715 Saint-Denis, Réunion, France unchanged on the deep fore reef. Turfs on endoliths were consistently preferred in both seasons but their contribution increased from $45 \%$ in the cool to $70 \%$ of bites in the hot season. Electivity for turfs on crustose corallines shifted from random feeding in the hot (27\% of bites) to selection in the cool season (47\% of bites). Feeding pattern changed diurnally with more bites taken from crustose corallines and turfs on crustose corallines during morning. During the rest of the day, bites from turfs on endoliths predominate. $S$. ferrugineus shows limited capacity to exploit seasonal increases in the biomass of foliose and canopy forming macroalgae, despite indications of energetic limitation during the cool season.

Keywords Seasonality - Grazing - Resource selection · Algae $\cdot$ Scarus ferrugineus

\section{Introduction}

Herbivorous fishes have long been recognized as a major force structuring benthic communities on coral reefs (Randall 1961; Hay et al. 1983; McClanahan et al. 2003; Burkepile and Hay 2009). Parrotfishes (family Labridae) are probably among the most important components of the grazing guild owing to their high biomass and wide distribution and a feeding mechanism that is highly specialized for scraping algae and detritus from carbonate substrates (Russ 1984; Choat 1991; Mumby et al. 2007; Fox and Bellwood 2007; Sotka and Hay 2009). Within this family, species differ in their feeding mode (for example excavator vs. scraper), microhabitat use, and food selection (Bellwood and Choat 1990; Bruggemann et al. 1994b; Hoey and Bellwood 2008). Also size determines the functional role of a species, which changes during 
ontogeny (Lokrantz et al. 2008; Bonaldo and Bellwood 2008). Assessment of the impact of parrotfishes on coral reef benthic communities therefore requires a detailed analysis of their feeding ecology, not only at the species level but also among the different size and life-history stages of each species (Bellwood et al. 2003; Burkepile and Hay 2008; Bonaldo and Bellwood 2008).

Coral reefs are not restricted to oligothrophic, temporally stable oceanic environments (Hatcher 1997). Many coral reefs thrive in upwelling areas and in seasonal seas where significant temporal changes in benthic algal community are typical (Diaz-Pulido and Garzon-Ferreira 2002; Ateweberhan et al. 2006a). Such areas offer unique situations to study the responses of grazers to the changing biotic and abiotic conditions. Despite this, the effect of seasonally changing food supply on the ecology of parrotfishes has not been studied extensively (Lefevre and Bellwood 2010). A notable exception is the detailed work of Clifton (1995) who reported significant changes in the reproduction and growth of Scarus iserti in Panama as a consequence of changes in the productivity of turf algae.

The southern Red Sea is characterized by monsoonassociated seasonal fluctuations in environmental conditions with high temperatures in summer (Edwards 1987). The resulting seasonal changes in the biomass and cover of algal functional groups (Ateweberhan et al. 2006a) are reminiscent of winter-spring shifts in the biomass of temperate rocky shores (Murray and Horn 1989; Gunnarsson and Ingolfsson 1995). This setting makes the fringing reefs of the Southern Red Sea an ideal environment to investigate the effects of extreme temperatures and seasonality on grazing and its role in mediating the interaction between algae and corals.

We present here the results on the feeding ecology of different life phases of the endemic Scarus ferrugineus in relation to seasonal changes in algal functional groups, studied on a fringing reef in the southern Red Sea. This species is the dominant parrotfish in the area. Despite its potentially important ecological role, virtually nothing is known of the biology of this species. Specific questions we sought to answer were: How do different life phases of $S$. ferrugineus use benthic resources in different reef zones? Does the seasonal change in the availability of algal functional groups affect the feeding preference of the species?

\section{Materials and methods}

Study site

The study was conducted between January 2006 and April 2008 on a fringing reef at the windward side of Sheikh Said Island near Massawa, Eritrea (15 $\left.35^{\prime} \mathrm{N} ; 39^{\circ} 29^{\prime} \mathrm{E}\right)$ (Fig. 1).

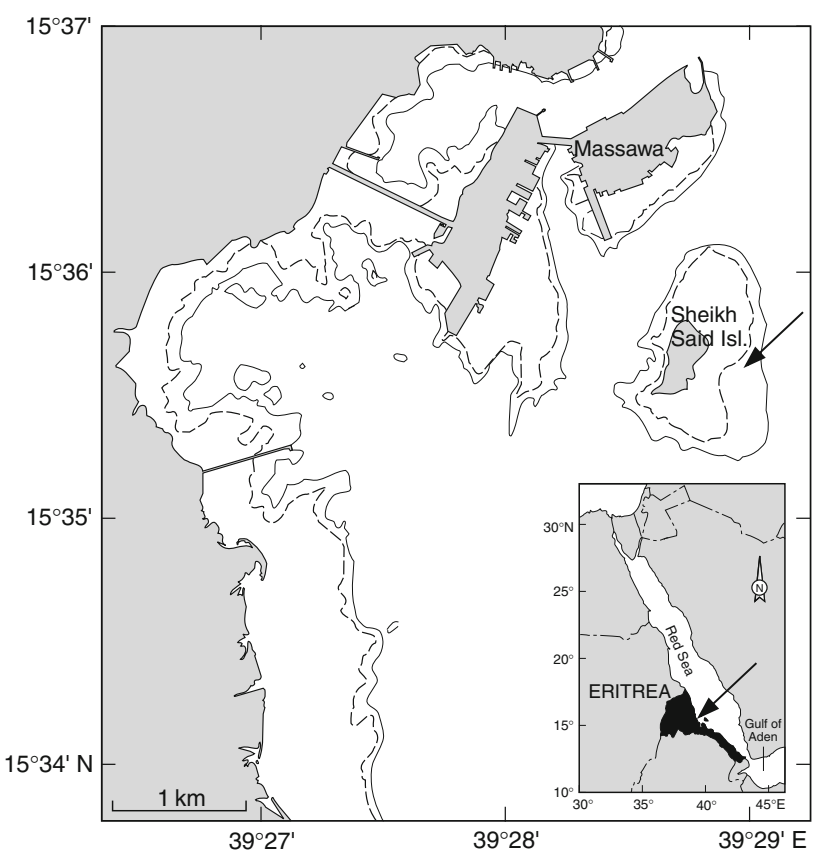

Fig. 1 Map of Massawa (Eritrea), southern Red Sea, showing Sheikh Said Island (arrow)

Four reef zones with distinct morphologies were identified: the reef flat, the reef crest, the shallow fore reef, and the deep fore reef. The reef flat is a 40- to 55-m-wide subtidal zone ( $0-1 \mathrm{~m}$ deep), mainly composed of consolidated limestone pavement and loose coral rubble. The reef flat as it is defined here comprises the inner, middle, and part of the outer reef flats described by Ateweberhan et al. (2006a). During the cool season, this area is covered by dense growths of Sargassum illicifolium on the landward side and by open stands of Turbinaria triquetra along the seaward margin. The reef crest ( $0-2 \mathrm{~m}$ deep) is a transition zone between the reef flat and the shallow fore reef and is partly exposed during extreme low tides. The substrate on the landward side is composed of limestone pavement and loose coral rubble. The deeper side of the reef crest is largely covered by living and dead corals, mainly Porites and Montipora. The shallow fore reef (2-6 m deep) is characterized by large colonies of massive Porites scattered in a zone dominated by sand and rubble. Encrusting Echinopora corals are abundant on the shallower part of this zone. The deep fore reef (6-10 $\mathrm{m}$ depth) has the highest coral cover dominated by Lobophyllia and Echinopora. In its deepest part, the soft coral Xenia covers much of the bottom surface down to a depth of $\sim 13 \mathrm{~m}$. Deeper down coral growth is absent giving way to a gently sloping sandy expanse.

The study site is in a good condition with minimal fishing activity restricted to few canoe fishermen targeting predatory fishes. The absence of spear fishing permits behavioral observations at close range. 
Environmental conditions

The southern Red Sea experiences significant monsoonassociated changes in environmental conditions (Edwards 1987). Two distinct seasons are identifiable: a cool season that extends from November to April which is associated with the north-eastern monsoon and a hot season spanning May to October and associated with the south-western monsoon (Ateweberhan et al. 2006b). At the study site, mean monthly water temperatures at $2 \mathrm{~m}$ depth range from $27.7^{\circ} \mathrm{C}$ during the cool to $33.4^{\circ} \mathrm{C}$ in the hot season (Ateweberhan et al. 2006a). This is associated with significant changes in the composition and biomass of the benthic algae (Ateweberhan et al. 2006a). Briefly stated, the cool season is characterized by the building-up of large stands of foliose and canopy forming macroalgae in the reef flat and parts of the reef crest, and high biomass of crustose corallines in the reef crest and shallow fore reef. The hot season induces significant reduction in the cover and biomass of macroalgae and crustose corallines while turf algae increase.

\section{Study animal}

Scarus ferrugineus (Frosskål, 1775) is a member of the family Labridae, endemic to the Red Sea and the Arabian Sea, and a dominant scarid on the reefs of the southern Red Sea. It is a diandric protogynous hermaphrodite (Randall and Ormond 1978). The terminal-phase males (TP) are colorful with shades of green, yellow, and pink and dominate the large size classes. The initial-phase (IP) fish are reddish-brown to brown and comprise the smaller size classes. At the study site, maximum size recorded for TP fish is $36 \mathrm{~cm}$ while the IP fish reach $26 \mathrm{~cm}$.

\section{Habitat description}

Surveys of available substrates and potential food sources were made during the peaks of cool (January to March) and hot (July to September) seasons. Relative abundance of substrates and algal vegetation types of the reef crest, shallow fore reef, and deep fore reef zones was determined using chain-link transects (Bruggemann et al. 1994c). The reef flat was excluded as our visual surveys indicated very low numbers of Scarus ferrugineus in this zone.

In each zone, a 99-m-long line transect was laid parallel to the coast at a haphazardly selected location and fixed with metal stakes at intervals of $30 \mathrm{~m}$. This transect provided the backbone of two parallel grids of 33 squares $(3 \times 3 \mathrm{~m})$ on either side. Each of the 66 quadrats was allocated a unique number of which 20 were randomly selected as permanent sampling locations for both the cool and hot seasons.
At each selected quadrat, two 3-m-long chains of 150 links each were laid out along two sides of the selected quadrat, parallel and perpendicular to the shore and following the contours of the substrate. The substrate type and biota under (the welding point of) each chain link were determined visually. The following substrate categories were used: living coral, dead coral, coral rubble, limestone pavement, and sand. Living corals were identified to genus level. Where possible, the origin of dead coral substrates was also identified to genus level. Moreover, the orientation of dead coral substrate was differentiated as horizontal, edge, vertical, overhanging, and coral base.

The biota growing in or on dead coral, coral rubble, and limestone pavement were classified following Bruggemann et al. (1994c) as turfs growing on endolithic algae (henceforth turfs on endoliths), turfs growing on crustose coralline algae (henceforth turfs on crustose corallines), bare crustose coralline algae, turfs growing on boring sponges (henceforth turfs on sponges), invertebrates other than corals (henceforth invertebrates) or macroalgae.

\section{Bite description}

Feeding behavior of Scarus ferrugineus was recorded within the marked transects and in approximately the same periods during which the benthic surveys were made. A haphazardly selected fish was allowed to acclimate to the observer for $3 \mathrm{~min}$ during which time the life phase, fork length, time of day, and the approximate location were recorded. Only one bite was described per fish. Resampling of individual fish was minimized by swimming away from the area where the last bite was described before selecting another fish. Moreover, the large population size of the species at the study site makes resampling of the same individual unlikely.

To ensure random sampling of bites, a number between 5 and 15 was randomly selected before each dive to represent the $n$th bite to be described. The exact location of the $n$th bite was spotted and the nature of the substrate, its orientation, and the biota covering it were noted. Moreover, the microtopography (convex, flat, concave), scar production, and the 'foray' length (sensu Bellwood and Choat 1990) were recorded.

Possible diurnal change in resource use was investigated by sampling bites during the morning $(0,600-1,100 \mathrm{~h})$, around noon $(1,100-1,300 \mathrm{~h})$, and in the afternoon $(1,300-1,800 \mathrm{~h})$. All field work was conducted by the same observer (Y.A.).

Statistical analysis

Multivariate tests of similarity (ANOSIM) were used to compare the composition of substrates, live coral genera, 
and biota between the seasons in each zone and among zones in each season. Whenever the differences are significant, the contribution of categories to the average dissimilarity was assessed based on similarity percentage analysis (SIMPER). SIMPER and ANOSIM tests were conducted using PRIMER-E v 5.2 (Clarke and Warwick 2001).

Correspondence analysis was used to assess the degree of association between the orientation of dead coral substrate parts and the biota covering it. Life phase-related differences in resource utilization were studied, controlling for zone and season, at the level of substrate, food (biota), and dead coral genera using two-way contingency tables followed by chi-square tests. Differences in feeding between the seasons and day times were compared similarly using chi-square.

Selection of grazing substrates, biota, and dead coral types was tested by comparing their utilization to availability in each zone and season using chi-square tests. Preference was analyzed using Ivlev's electivity index (Eq. 1) (Lechowicz 1982). Values for Ivlev's index range from -1 (avoidance) to 1 (preference). Zero indicates random feeding. Bootstrapping procedure (300 simulations) was conducted on individual bites [keeping resource abundance constant (Smith 1982)] to estimate the confidence limits of electivity values. Ivlev's electivity values were tested against random feeding by looking if the confidence interval included zero or not.

$E=\frac{r i-p i}{r i+p i}$

$B^{\prime}=1 / \sum_{i=1}^{R}\left(p_{i}^{2} / q_{i}\right)$

Niche breadth was estimated using the weighted version of Levin's measure (Eq. 2) (Hurlbert 1978). For the calculation of niche breadth, all potential food sources in the habitat were considered. This measure can take values between zero (specialist feeder) and one (generalist feeder). Seasonal difference in niche breadth was tested using Z-test (Smith 1982).

Resource selection was further investigated using foray lengths, assuming that longer forays are indicators of preference (Bruggemann et al. 1994c). Forays were classified into nine classes of 1-3, 4-6, 7-9, 10-12, 13-15, $16-18,19-21,22-24,>25$ bites. Differences in the frequency distribution of forays for the different biota items were then tested by chi-square tests controlling for life phase, season, and zone. Difference in scar productionexpressed as the percentage of total bites producing visible grazing scars-among life phases was analyzed by ANCOVA, taking percentage of scars as a dependent variable, life phase as a fixed factor, and fish fork length as a covariate.

Whenever some cells in the contingency tables contained very low expected frequencies, they were grouped together and Fisher's exact test (FET) was used instead of chi-square. All chi-square, ANCOVA, and correspondence tests were conducted on SPSS for Windows v 16.0 (2007).

\section{Results}

Substrate composition

A total of 29,390 chain-link points were described during this study. To compare zones, seasonal substrate composition data were pooled since these did not differ (ANOSIM: Global $-r=0.066,-0.029$ and $-0.069, P=0.061,0.852$, and 0.974 , for the reef crest, shallow fore reef, and deep fore reef, respectively). Substrate composition was significantly different between the zones (ANOSIM: Global- $r=0.351$, $P=0.001$ ) and between each pair of zones (ANOSIM: Global $-r=0.347-0.373$ and $P=0.001$ in each case). Primary contributors (SIMPER) to this difference were the high living coral cover in the deep fore reef, the large cover of sandy areas in the shallow fore reef, and the high extent of limestone pavement in the reef crest. Among the three zones, the reef crest has the largest proportion of the substrates suitable for algal growth and hence for parrotfish grazing. There, the sum of cover by coral rubble, dead coral, and limestone pavement is $61 \%$. This figure is $50 \%$ on the shallow fore reef and $32 \%$ on the deep fore reef.

Twenty-one coral genera were identified. The deep fore reef had the highest generic richness with 21 genera followed by the shallow fore reef and the reef crest with 19 and nine genera, respectively. Generic diversity based on Jaccard's index was highest on the deep fore reef (0.6644) followed by shallow fore reef (0.5491) and reef crest (0.4889). Coral community composition between zones was compared by pooling seasonal data as there was no difference between the seasons (ANOSIM: Global- $r=-$ $0.015,-0.049$ and $0.056, P=0.583,0.986$, and 0.114 for reef crest, shallow fore reef, and deep fore reef, respectively). Coral composition was significantly different between zones (ANOSIM: Global- $r=0.505, P=0.001$ ), and all pairwise tests were also significant (ANOSIM: Global- $r=0.208-0.794, P=0.001$ in each case). The primary contributors to this difference were the four dominant coral genera: Porites, Echinopora, Lobophyllia, and Montipora. Montipora and Porites are the characteristic of the reef crest, Porites and Echinopora of the shallow fore reef, and Lobophyllia and Echinopora of the deep fore reef. All coral genera contributed to the pool of 
dead coral substrates in direct proportion to their abundances in their living form. This is confirmed by a significant positive correlation between the cover by dead and living coral of each genera.

\section{Composition of biota growing on limestone substrates}

The most abundant categories of biota were turfs on crustose corallines, turfs on endoliths, and crustose corallines occupying, respectively, 27-51, 24-45, and 12-38\% of hard substrates, depending on season. The highest cover of macroalgae was $9.8 \%$, recorded on the reef crest during the cool season. Invertebrates attained a cover of $10 \%$ on the deep fore reef while they were nearly absent in the reef crest and the shallow fore reef (Fig. 5).

Percentage composition of the biota was significantly different between the seasons in the reef crest and shallow fore reef (ANOSIM: reef crest: Global- $r=0.266, P=$ 0.001; shallow fore reef: Global- $r=0.194, P=0.001$ ). The primary cause of this difference is the significant increase in cover of crustose corallines and a corresponding decline in turfs on crustose corallines and turfs on endoliths during the cool season (Fig. 5). In the reef crest, increase in the cover of macroalgae from 0.7 to $10 \%$ contributes about $12 \%$ of the dissimilarity between the seasons. Biota in the deep fore reef remained unchanged in the course of the year (ANOSIM: Global $r=-0.044, P=0.76$ ).

Biota were not randomly distributed across dead coral surfaces with different orientation (correspondence analysis: $P=0.000$ ), although substrate orientation explained only $14.6 \%$ of the variation in biota composition. About $97.4 \%$ of this variation was explained by both the first $(91.4 \%)$ and the second axis (6\%). Briefly stated, crustose corallines are mainly associated with coral bases and overhanging surfaces, while turfs on endoliths are highly associated with exposed horizontal surfaces. Vertical surfaces were largely covered by turfs on crustose corallines and invertebrates.

Patterns of feeding in space and time

\section{Substrate choice}

A total of 1,606 bites were described, 645 during the cool and 961 during the hot season. Dead corals are the most used feeding substrates for all the life phases of Scarus ferrugineus (Fig. 2), being the target of $83 \%$ of bites in IP fish, $80 \%$ in TP fish, and $92 \%$ in juveniles. Limestone pavement sustaining $8.9 \%$ and coral rubble sustaining $6.9 \%$ of bites are the second and third most exploited substrates. Bites from living corals and sand represented 1.2 and $0.2 \%$ of total recorded bites, respectively.
All life phases showed preference for certain substrates, indicated by the significant difference between utilized and available substrates $\left(\chi^{2}=46.78-638.51, \quad P=0.000\right.$, $d f=4$ for all life phases in each zone). Electivity indices show that dead coral is highly preferred (Fig. 2). Limestone pavement is used by TP and IP fish at random, although IP fish show preference for this substrate on the shallow fore reef. Living corals and sand are strongly avoided. Coral rubble is avoided in both the shallow fore reef and reef crest zones, while it is used at random in deep fore reef zone.

Utilization of dead coral genera did not differ between life phases or between seasons. Hence, selectivity tests within each zone were conducted by pooling data from life phases and seasons. S. ferrugineus is highly selective regarding dead coral substrates (reef crest: $\chi^{2}=38.48$, $d f=5, \quad P=0.000 ; \quad$ shallow fore reef: $\chi^{2}=253.93$, $d f=14, P=0.000$; deep fore reef: $\chi^{2}=92.75, d f=15$, $P=0.000)$. Dead Porites substrates were the most targeted feeding substrates. In the reef crest and shallow fore reef zones, bites on this substrate constituted $80 \%$ of the total. On the deep fore reef, most bites were taken from dead Echinopora (43\%) and Porites (15\%) colonies. Ivlev's electivity was calculated for the common genera (Fig. 3). Dead Porites substrates are consistently preferred in all three zones irrespective of their availability. Echinopora is avoided in the reef crest while it is preferred in the shallow fore reef and deep fore reef zones. All other dead coral substrates are either avoided or used in equal proportion to their occurrence, except for Montipora in the deep fore reef and Platygyra in the shallow fore reef where these substrates were preferred.

Regarding substrate microtopography, all life phases of $S$. ferrugineus took most bites from convex surfaces (Fig. 4). TP targeted these significantly more than IP or juvenile fish $\left(\chi^{2}: d f=4, P=0.027\right)$.

\section{Choice of biota}

Analysis of food choice was restricted to the biota growing on dead limestone substrates. Bites on living corals and sand were excluded owing to their low percentage contribution.

Utilization of biota did not differ between life phases in both seasons and in each of the three reef zones. Therefore, data from life phases were pooled for testing selectivity in each zone and season. Utilization of biota by $S$. ferrugineus was significantly different between seasons on the reef crest and the shallow fore reef (FET: reef crest: 18.247, $P=0.000$; shallow fore reef: $30.778, P=0.000$; Fig. 5). Standardized residuals of the chi-square test indicated that a significantly higher utilization of turfs on endoliths during the hot season was the primary cause of this difference. Moreover, analysis of percentage dissimilarity (SIMPER) 

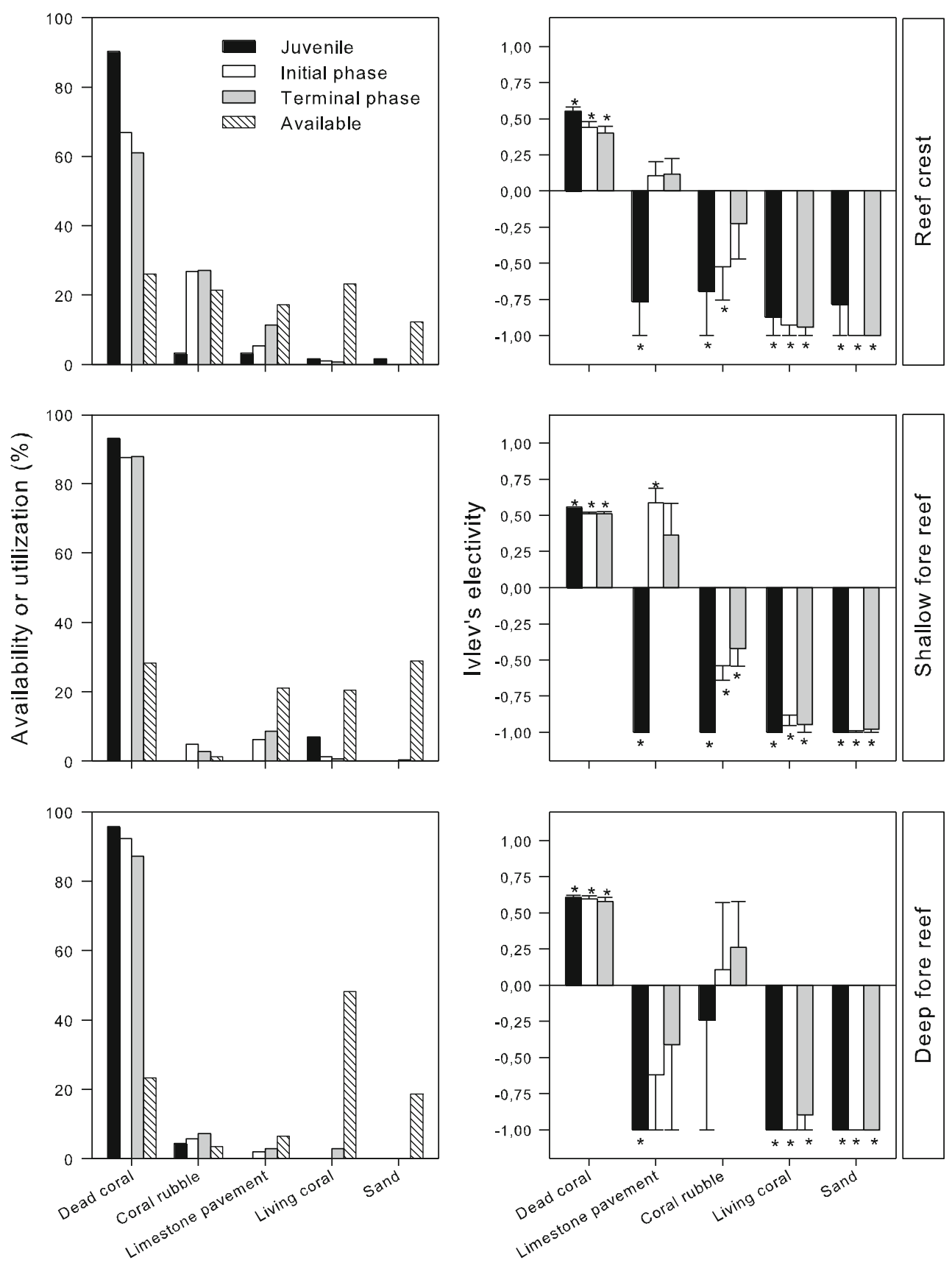

Substrates

Fig. 2 Scarus ferrugineus. Availability and utilization (left) and electivity (right) of the major substrate categories by life phase and reef zones. Bars are bootstrap-generated $95 \%$ confidence intervals. Asterisks indicate significant difference from random feeding

indicated that turfs on endoliths followed by turfs on crustose corallines-both food types contributing to over $85 \%$ of the dissimilarity - are the primary causes of this seasonal difference. On the deep fore reef, there was no seasonal difference in utilization (FET: $2.503, P=0.286$ ).

During each season and in each zone, exploitation of food resources was significantly different from their occurrence, indicating that $S$. ferrugineus is a selective feeder. Ivlev's electivity values (Fig. 5) show that turfs on endoliths are preferred in each season and zone. Electivity for turfs on crustose corallines shifted from avoidance on the shallow fore reef and random feeding on the reef crest during the hot season to significant preference during the cool season (Fig. 5). In the deep fore reef, turfs on crustose corallines were either avoided (hot season) or used in proportion to their occurrence (cool season). Here, the rare 
Fig. 3 Scarus ferrugineus. Selection of dead coral substrates by coral genus and reef zone. Bars are bootstrapgenerated $95 \%$ confidence intervals. Asterisks indicate significant difference from random feeding

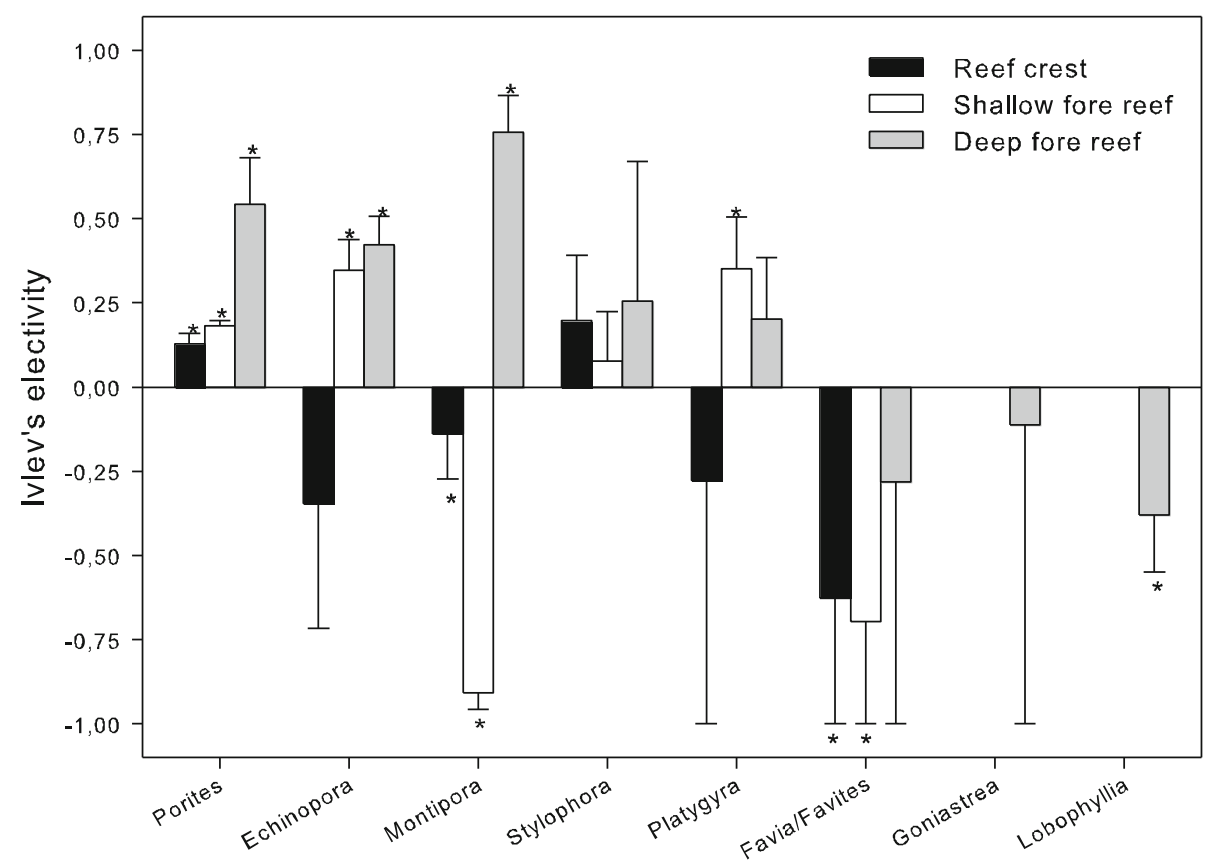

Coral genus

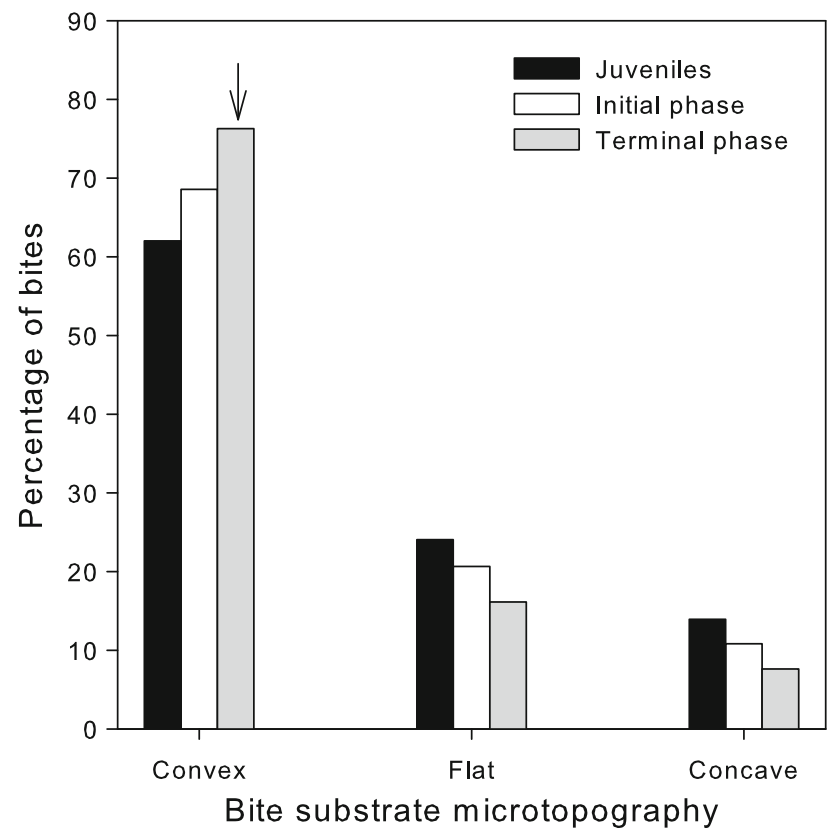

Fig. 4 Scarus ferrugineus. Use of substrates with different microtopography by each life phase. Arrow indicates that TP use convex surfaces significantly higher than juvenile and IP

combination of turfs growing on boring sponges were grazed preferentially in the hot season while it was used at random during the cool season. All other potential food items were avoided in all zones during both seasons.

The seasonal change in utilization parallels the concomitant change in the availability of the two main food items. Lower cover in turfs on endoliths-the main food item-during the cool season leads to an increased inclusion of turfs on crustose corallines from around $30 \%$ in the hot to $47 \%$ in the cool season. This corresponds to a decline in the utilization of turfs on endoliths from around $70 \%$ in the hot to $54 \%$ in the cool season.

Values of the niche breadth ranged from a minimum of 0.16 during the hot season on the deep fore reef to a maximum of 0.53 during the hot season on the reef crest (Fig. 6). Overall, S. ferrugineus is a specialist feeder in all zones and seasons. Niche breadth is narrowest in the deep fore reef where the resource space is principally occupied by living corals, and it is widest in the reef crest where the preferred food items are more abundant. In the shallow fore reef, there was no seasonal difference in niche breadth. In the reef crest, $S$. ferrugineus has a significantly broader feeding niche in the hot compared to the cool season. The opposite is observed in the deep fore reef zone.

Foray size as indicator of feeding preference

Recorded foray lengths ranged from 1 to 35 bites. Data from seasons, life phases, and zones were pooled since these did not affect foray size class distribution (FSCD). There was a significant difference in FSCD among biota (FET: 105.204, $P=0.001$ ). Stepwise exclusion procedure revealed that the cause of the significance was turfs on endoliths and turfs on crustose corallines. With the exclusion of these two food types, FSCD of the remaining biota 

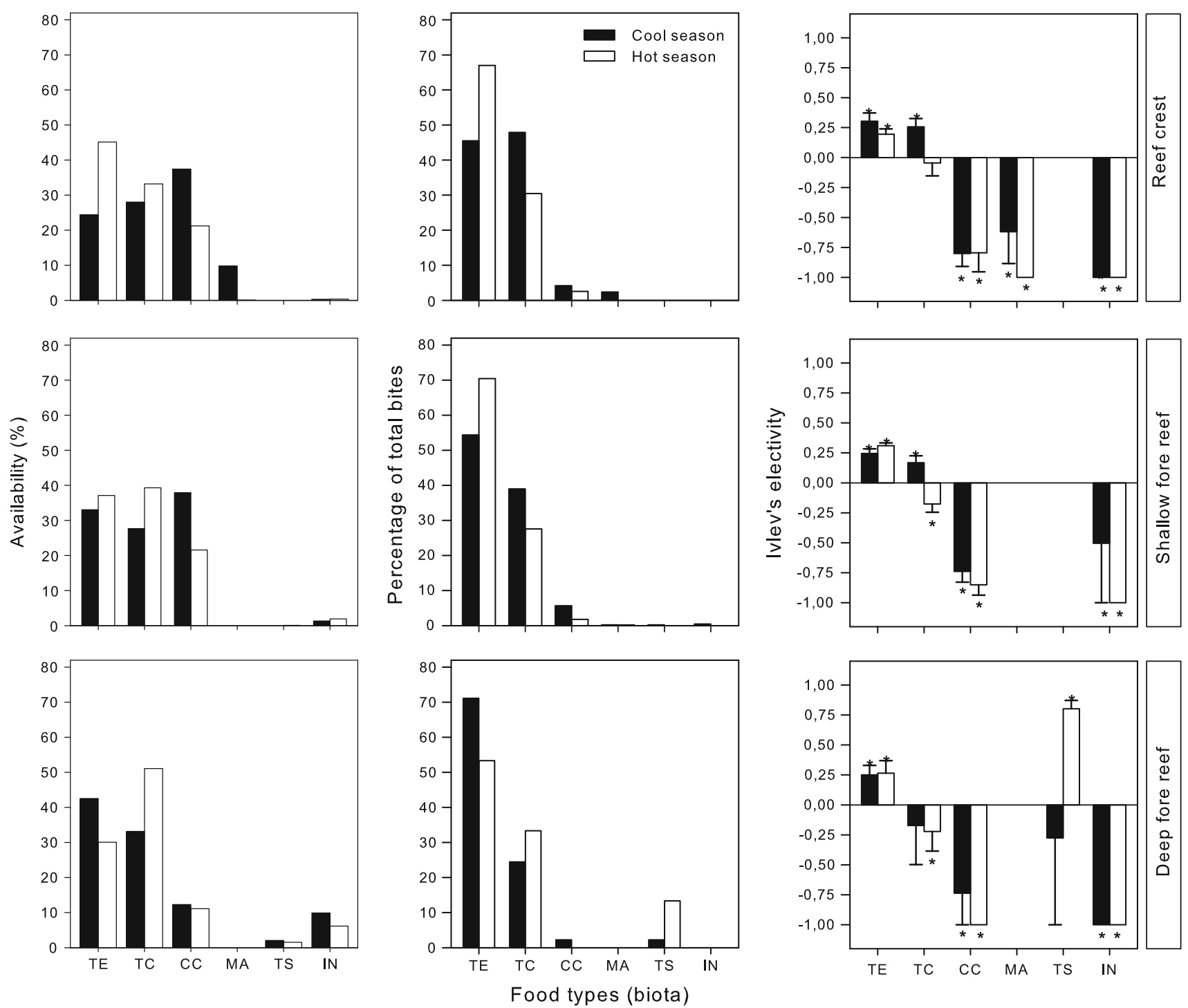

Fig. 5 Scarus ferrugineus. Availability (left), utilization (center), and electivity (right) of the major biota at different reef zones and two seasons. Bars are bootstrap-generated $95 \%$ confidence intervals.
Asterisks indicate significant difference from random feeding. TE turfs on endolithic algae, $T C$ turfs on crustose corallines, $C C$ crustose corallines, $M A$ macroalgae, $T S$ turfs on sponge, $I N$ invertebrates is not different between each other (FET: 40.412, $P=0.165)$. The less preferred biota such as crustose corallines, macroalgae, and invertebrates were characterized by short forays, ranging 1-9 bites. On the other hand, turfs on endoliths and turfs on crustose corallines were characterized by longer forays. A closer examination of these two main food types was done for each life phase separately. For IP and TP fish, the FSCD of turfs on endoliths is highly skewed to the right, indicating the prevalence of longer forays (Fig. 7) on this food type compared to those taken from turfs on crustose corallines (FET: IP: $15.272, P=0.034$; TP: $16.589, P=0.019)$. For juveniles, the difference between these two food types was not significant (FET: 3.681, $P=0.312$ ).
Diurnal changes in food choice

Comparison of biota and surface choice among three periods of the day was done for IP and TP fish alone, as not enough morning bites were recorded for juveniles. Biota selection by IP and TP fish was similar for each period of day; therefore, data from both life phases were pooled for subsequent tests. During the morning, choice of biota was similar in both the cool and hot seasons (FET: 7.885, $P=0.129)$. In contrast, it varied significantly with season for noon and afternoon periods-parts of the day when the bulk of the bites are taken (FET: noon: 10.352, $P=0.014$; afternoon: 15.092, $P=0.009$ ); diurnal changes in resource use were therefore analyzed for each season separately. 


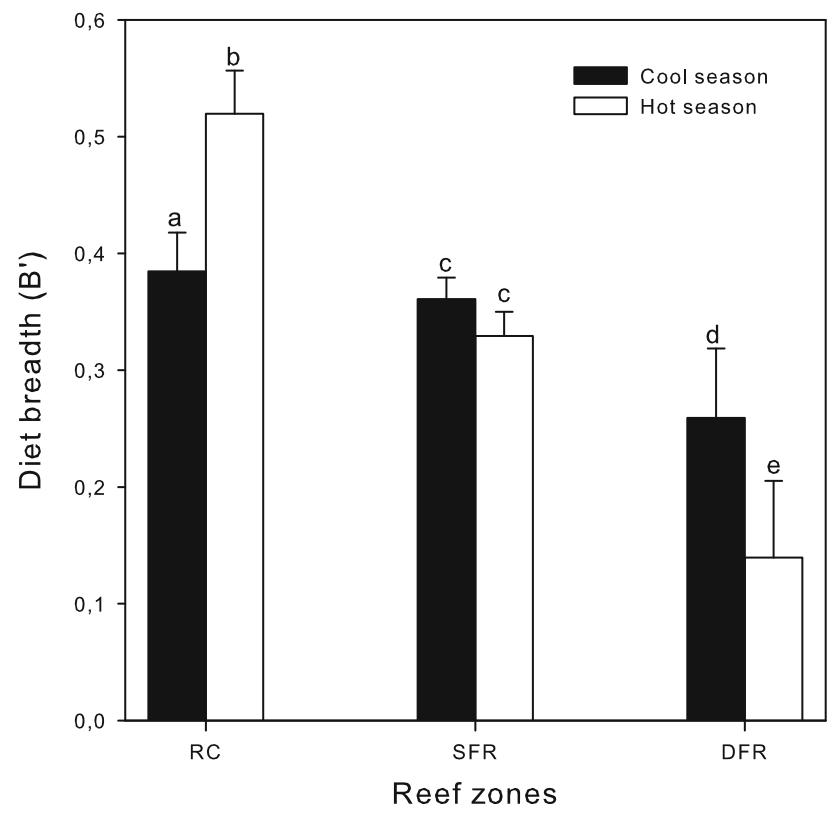

Fig. 6 Scarus ferrugineus. Feeding niche breadth of adult fish by reef zone and season. Different letters above bars indicate significant seasonal difference within each zone

For each season, biota choice differed significantly among daytime periods (FET: cool season: 47.778, $P=0.000$; hot season: $13.904, P=0.019$; Fig. 8). Stepwise elimination procedure revealed that resource use in the morning is significantly different from the other two periods of day, which were not different from each other. In general, during the morning, more bites were taken from less preferred food types such as turfs on crustose corallines and crustose corallines. During noon and afternoon, the majority of bites are taken from turfs on endoliths.

Similarly, choice of feeding surfaces was significantly different between the three periods of day in both seasons (FET: cool season: 63.721, $P=0.000$; hot season: 18.164 , $P=0.004$; Fig. 8). Stepwise elimination indicated that choice of feeding surface in the morning differed significantly from the other two periods that were similar to each other. In summary, S. ferrugineus feeds more from coral bases and vertical surfaces in the morning than during other times of day. During the afternoon, $60 \%$ of bites are taken from horizontal surfaces, as opposed to $40 \%$ in the morning.

\section{Scraping capacity}

Percentage of bites producing visible grazing scars increased significantly with fish size (ANCOVA: $F_{(2,9)}=$ 19.766, $P=0.003$; Fig. 9). For the largest size class, $70 \%$ of bites produced scars. Life phases did not differ in their capacity to produce scars (ANCOVA: $F_{(2,9)}=0.05, P=$ 0.946). The effect of dead coral genus on scar production
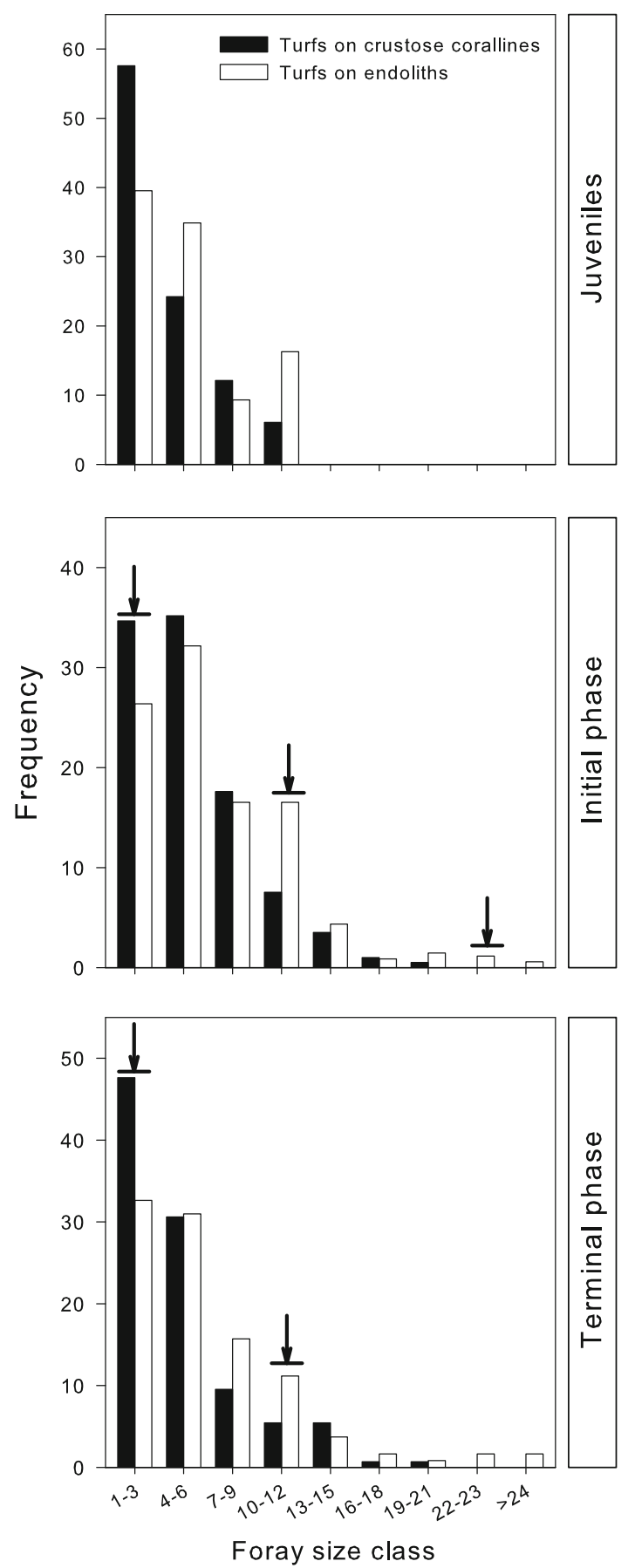

Fig. 7 Scarus ferrugineus. Frequency distribution of foray size classes for the two main biota. Arrows on bars show the foray classes that made significant contributions to the difference

was tested for the common coral genera such as Echinopora, Lobophyllia, Montipora, Platygyra, Porites, and Stylophora. The dead coral genus affected the percentage of bites producing scars significantly (ANCOVA: $F_{(2,81)}=3.050$, $P=0.015)$. Pairwise contrasts revealed that the overall difference was caused by Montipora substrates, showing 


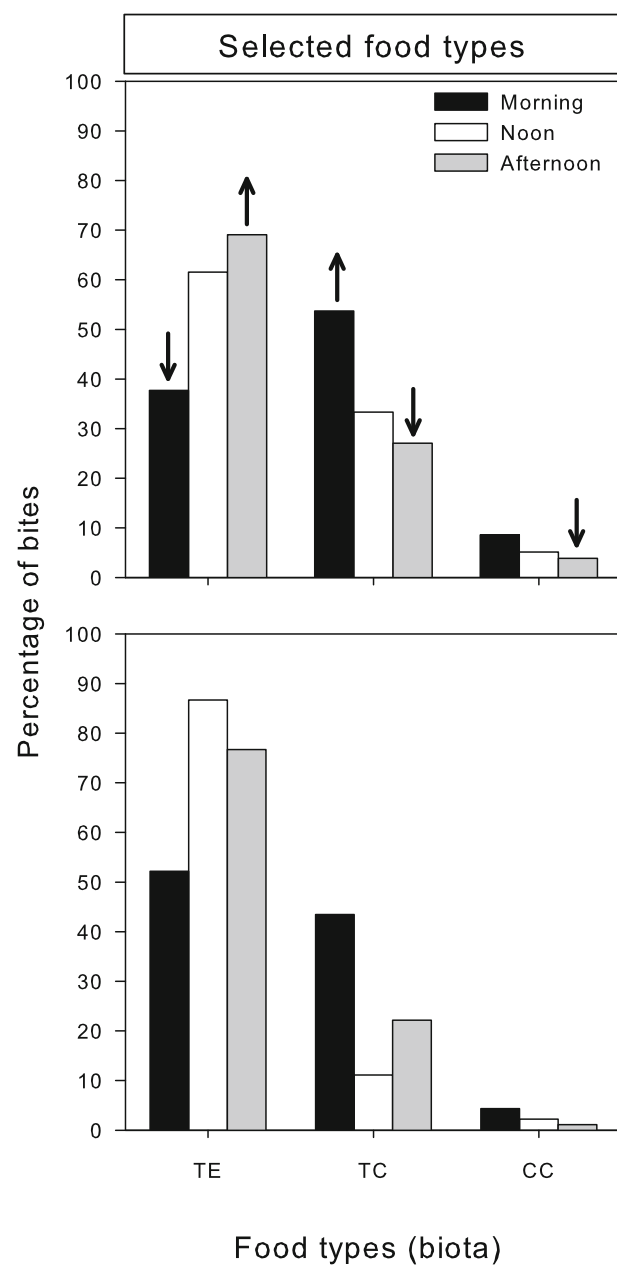

Fig. 8 Scarus ferrugineus. Diurnal change in the percentage use of biota and dead coral surfaces during the cool and hot seasons. Arrows indicate components that were used significantly less (downward

higher incidence of bite scars than Stylophora and Echinopora (ANCOVA pairwise contrasts: $P<0.05$ for both).

\section{Discussion}

Spatial and seasonal aspects of resource abundance

Each of the three reef zones studied offered a different suite of substrates and biota for grazing fish. The cover of living corals $(20-48 \%)$ is among the highest reported for the southern Red Sea (Zekeria and Videler 2000). Folios and canopy forming macroalgae are restricted to the shallow parts of the reef crest and the reef flat, where their density and biomass is controlled by seasonal changes in environmental conditions (Ateweberhan et al. 2006a). The absence of macroalgae in the deeper parts of the reef throughout the year strongly suggests that grazing prevents the development of macroalgae in these zones (this study).
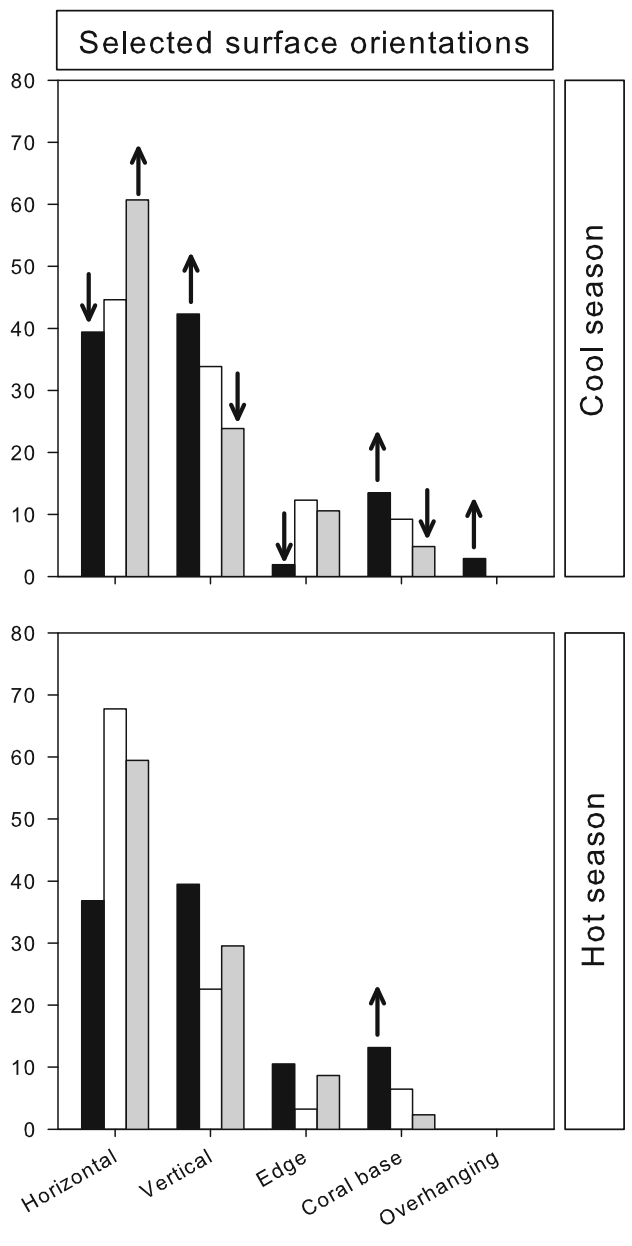

Orientation of surface

pointing) or more than expected (upward pointing). See caption of Fig. 5 for explanation of the acronyms

The reef crest with its high cover of epilithc algae (Klumpp and McKinnon 1992; this study) and high productivity (Klumpp and McKinnon 1989) appears to be the primary zone of foraging for coral reef grazers as indicated by their high densities at this zone (Bouchon-Navaro and HarmelinVivien 1981; Russ 2003; Fox and Bellwood 2007).

The composition of the biota also varied for the different parts of dead coral substrate. The prevalence of crustose corallines on cryptic surfaces such as coral bases, overhangs, and the understory of algal canopies is common and is attributed to factors such as low grazing, low sedimentation and shading from intense light (Baynes 1999; Caragnano et al. 2009). Conversely, the dominance of turf algae on exposed surfaces may be related to their ability to tolerate high light intensities, sedimentation, and intense grazing (Carpenter 1985; Hackney et al. 1989).

Resource abundance varied significantly with season in the two shallower zones but remained unchanged in the deep fore reef. This may be due to the smaller seasonal 


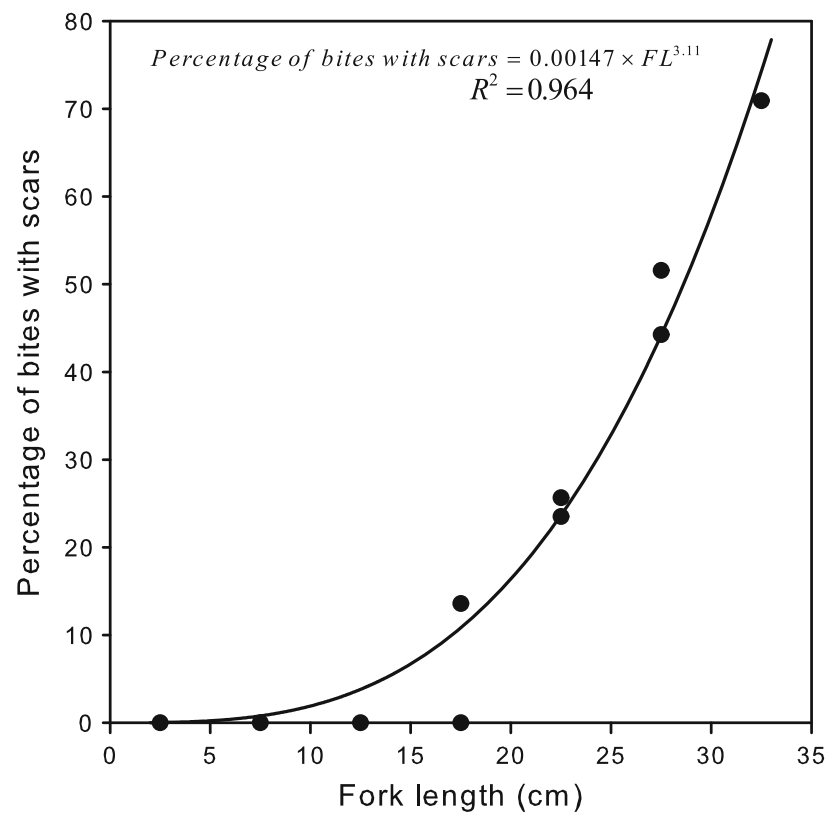

Fig. 9 Scarus ferrugineus. Percentage of bites that produce visible scars as a function of fish fork length $(F L)$

variations in temperature and irradiance at $10 \mathrm{~m}$ depth compared to the shallower areas. Hatcher and Larkum (1983) described a similar trend of decreasing seasonality with depth in the Great Barrier Reef (GBR). In the reef crest and shallow fore reef zones, crustose corallines and macroalgae (only on the reef crest) attain higher cover and biomass (Ateweberhan et al. 2006a) during the cool season. At the onset of the hot season, rising temperatures and irradiance cause crustose corallines, foliose, and canopy forming macroalgae to decline (Ateweberhan et al. 2005a,b, 2006b), creating opportunity for the tolerant turfs to increase in cover (Ateweberhan et al. 2006a).

\section{Utilization of grazing substrates}

S. ferrugineus feeds almost exclusively from dead coral substrates with a small percentage of bites taken from coral rubble and limestone pavement. S. ferrugineus, as many other parrotfishes (e.g., Bruggemann et al. 1994b; Bellwood 1995), rarely bites on living corals. Preference for dead coral substrates is widely reported for many parrotfishes species in the Caribbean (Bruggemann et al. 1994b), GBR (Bellwood 1995), and Red Sea (Alwany et al. 2009). One possible explanation for this is the prevalence of preferred algal food types among the biota that occupy dead coral surfaces (Bruggemann et al. 1994b). Similarly, the underutilization of coral rubble appears to be related to the dominance of crustose corallines, a non-preferred food item, on this substrate. Limestone pavements being flat are prone to high sediment loads, a condition known to deter grazing in some herbivorous fishes (Bellwood and Fulton 2008).

Not all dead coral substrates were equally targeted by $S$. ferrugineus. Porites is the most consistently preferred dead coral receiving the bulk of the bites, particularly in the reef crest and shallow fore reef zones. Comparable high selectivity is reported for the excavating parrotfish Sparisoma viride that prefers to feed on dead Montastrea annularis and Madracis mirabilis colonies (Bruggemann et al. 1994c). This was attributed to the relatively low skeletal density of these substrates and the resulting higher yield per bite. Other characteristics of these commonly targeted coral genera that may be selected for are their massive growth form and their relatively smooth surface (due to their small calyx sizes). Besides permitting relatively high yields, preference for these genera may be linked to the ease at which medium-sized parrotfishes can take bites without damaging their dentition (Bonaldo et al. 2007). Parrotfish grazing efficiency may thus be limited by the surface characteristics of the substrate. Rugged and branching structures can function as grazing refuges for macroalgae (Bennett et al. 2010).

Juveniles differed from the adults in that they restricted their bites exclusively to dead coral colonies. This may be due to the increased predation risk on flat open spaces (Connell and Jones 1991) where limestone pavement and coral rubble are predominant.

Most bites of S. ferrugineus targeted convex surfaces. This contrasts with reports showing that excavators use convex surfaces more than scraping species do (Bellwood and Choat 1990; Bruggemann et al. 1994b). A possible explanation for this may be a lack of competition for this niche from excavating species, such as Chlorurus sordidus, whose abundance in the present study site is an order of magnitude less than that of $S$. ferrugineus.

\section{Choice of biota}

Similarity in resource use among the different life phases of $S$. ferrugineus is in agreement with similar reports on other parrotfishes (Bruggemann et al. 1994b; Bonaldo et al. 2006). However, post-settlement scarids are omnivorous including a large proportion of crustaceans and foraminifera in their diet (Bellwood 1988). The transition to a diet composed of epilithic algal community is estimated to occur between sizes of $1.5-3 \mathrm{~cm}$ (Chen 2002). The juvenile size classes included in this study $(4-8 \mathrm{~cm})$ are therefore likely to represent individuals that are past this omnivorous phase.

S. ferrugineus is a selective feeder predominantly foraging on turfs on endoliths and turfs on crustose corallines. These represent $>90 \%$ of the bites during both seasons and in all reef zones. Crustose corallines, macroalgae, and 
living corals are consistently underutilized compared to their availability. Preference for turfs on endoliths has been reported for two other parrotfishes from the Caribbean (Bruggemann et al. 1994b, c). Most other studies on parrotfish feeding preference have not made the distinction between turfs growing on endoliths and those growing on crustose corallines (e.g., Hatcher and Larkum 1983; Bellwood 1995). It is therefore difficult to compare their results with our findings. Bruggemann et al. (1994c) analyzed the nutritional quality and biomass of the different epilithic algal communities in the Caribbean and concluded that turfs on endoliths have higher nutritional quality as well as biomass compared to turfs on crustose corallines. Moreover, the higher biomass of turfs on endoliths is likely to contain higher concentration of the detritus (Purcell and Bellwood 2001; Wilson et al. 2003), which has been shown to be nutritionally richer than epilithic algae alone (Wilson et al. 2003).

The endolithic component of turfs on endoliths can make up 32-46\% of the net community production on carbonate substrates (Tribollet et al. 2006). This constitutes a significant potential source of energy for those species that are capable of denuding the substrate-namely largebodied scrapers and excavating species. While all life phases of $S$. ferrugineus target the same biota, the actual intake may differ among life phases due to size-related differences in their scraping capacities (Fig. 9) (Lokrantz et al. 2008; Bonaldo and Bellwood 2008). Large TP fishowing to their higher scraping capacity — can be expected to utilize this endolithic component to a greater extent.

\section{Diurnal changes in food selection}

The shift in feeding preference of S. ferrugineus in different daytime periods recorded in the present study is associated with changes in the exploitation of grazing surfaces with different orientation. Surfaces of different orientation are associated with different algal types, resulting in the observed diurnal shift in feeding selection. This feeding pattern appears to coincide with the predictions of the diel feeding hypothesis, which states that herbivorous fish optimize their food intake by targeting highly productive algae in the afternoon to harvest readily digestible photosynthetic products (Polunin and Klumpp 1989; Zemke-White et al. 2002). Indeed, production and nutritional quality in turf algal communities increases through the morning reaching its peak at noon (Bruggemann et al. 1994a; Zemke-White et al. 2002). In the southern Red Sea, S. ferrugineus seems to respond to the low nutritional quality of turfs in the morning both by lower feeding rates (Y.A., pers.obs.) and by including other, less preferred food sources. A combination of these two responses leaves turfs on endoliths relatively untouched until late morning. Related to this, grazers are known to respond to spatial differences in turf algal production by aggregating on areas with high production (Klumpp and Polunin 1990; Russ and McCook 1999; Russ 2003; Burkepile and Hay 2009). Together, these findings suggest a close link between algal turf community production and the spatial and temporal patterns of feeding in grazing fishes.

Recent studies on the nutritional ecology of scarids have indicated detritus as a dominant food source for this group (Choat et al. 2002; Crossman et al. 2005). At our study site, late night and morning periods are characterized by calm conditions that promote the deposition of particulate organic material (Purcell and Bellwood 2001; Crossman et al. 2001). If such detrital matter constitutes a primary food source, scarids can be expected to adapt their feeding pattern to optimize its intake by high feeding rates on horizontally exposed surfaces in the morning. This clearly contradicts our findings. However, the actual definition of 'detritus' also incorporates fresh photosynthetic products exuded by algal turfs, endolithic algae, and associated microflora. Recent studies have shown that the bulk of the organic matter in detritus is derived from the epilithic algae (Wilson et al. 2001, 2003), a significant portion that consists of freshly exuded photosynthetic products (Wilson et al. 2001). Quantity and quality of detritus will therefore be expected to have a similar diurnal rhythm as epilithic algae (Wilson 2002). Scarids targeting such organic matter would be expected to exhibit feeding patters similar to those observed in this study. Further studies are required to distinguish deposited detrital material from locally produced photosynthetic exudates and their utilization by grazing parrotfishes.

\section{Seasonal aspects of food choice}

Resource use in S. ferrugineus varied between the cool and the hot seasons, but only in the shallower reef zones where significant seasonal changes in the abundance of algal functional groups occurred. Reduced availability of turfs on endoliths - the preferred food type-in the cool season resulted in the increased utilization of the second important food type turfs on crustose corallines. This increased exploitation of turfs on crustose corallines however did not extend to crustose corallines and macroalgae, algal functional groups that become abundant during the cool season. Moreover, reduced availability of the primary food type did not result in an increase in the niche breadth. It appears that S. ferrugineus shows limited flexibility in resource use, feeding mainly on turfs associated with hard coral substrates. Given the low availability of their main food source and the lower feeding rates during the cool season, S. ferrugineus may well be energetically limited during this 
period of the year. This notion is supported by observations of low liver fat reserves and growth rates during the cool season (Y.A., pers. obs.).

Our results suggest that $S$. ferrugineus shows limited flexibility in its feeding behavior in the face of large seasonal changes in the composition and production of different functional groups of algae. In particular, the large seasonal build-ups of macroalgal biomass on the reef crest and reef flat remain largely unexploited. This is consistent with other studies (McClanahan et al. 1999; Bellwood et al. 2006; Ledlie et al. 2007; Mantyka and Bellwood 2007; Fox and Bellwood 2008) that have reported the limited impact of scarids on well-established mature macroalgal stands.

Acknowledgments We gratefully acknowledge the assistance of Negassi Ghirmay, Yosief Hiabu, Woldeselassie Hidray, and Siraj Mohammed and the support of the Netherlands Foundation for the Advancement of Tropical Research (WOTRO grant W84-589). We thank three reviewers for their valuable comments on the manuscript.

Open Access This article is distributed under the terms of the Creative Commons Attribution Noncommercial License which permits any noncommercial use, distribution, and reproduction in any medium, provided the original author(s) and source are credited.

\section{References}

Alwany MA, Thaler E, Stachowitsch M (2009) Parrotfish bioerosion on Egyptian Red Sea reefs. J Exp Mar Biol Ecol 371:170-176

Ateweberhan M, Bruggemann JH, Breeman AM (2005a) Seasonal dynamics of Sargassum ilicifolium (Phaeophyta) on a shallow reef flat in the southern Red Sea (Eritrea). Mar Ecol Prog Ser 292: 159-171

Ateweberhan M, Bruggemann JH, Breeman AM (2005b) Seasonal patterns of biomass, growth and reproduction in Dictyota cervicornis and Stoechospermum polypodioides (Dictyotales, Phaeophyta) on a shallow reef flat in the southern Red Sea (Eritrea). Bot Mar 48:8-17

Ateweberhan M, Bruggemann JH, Breeman AM (2006a) Effects of extreme seasonality on community structure and functional group dynamics of coral reef algae in the southern Red Sea (Eritrea). Coral Reefs 25:391-406

Ateweberhan M, Bruggemann JH, Breeman AM (2006b) Seasonal module dynamics of Turbinaria triquetra (Fucales, Phaeophyceae) in the southern Red Sea. J Phycol 42:990-1001

Baynes TW (1999) Factors structuring a subtidal encrusting community in the southern Gulf of California. Bull Mar Sci 64:419-450

Bellwood DR (1988) Ontogenetic changes in the diet of early postsettlement Scarus species (Pisces, Scaridae). J Fish Biol 33: 213-219

Bellwood DR (1995) Carbonate transport and within reef patterns of bioerosion and sediment release by parrotfishes (Family Scaridae) on the Great Barrier Reef. Mar Ecol Prog Ser 117:127-136

Bellwood DR, Choat JH (1990) A functional analysis of grazing in parrotfishes (Family Scaridae): the ecological implications. Environ Biol Fish 28:189-214

Bellwood DR, Fulton CJ (2008) Sediment-mediated suppression of herbivory on coral reefs: decreasing resilience to rising sea levels and climate change? Limnol Oceanogr 53:2695-2701
Bellwood DR, Hoey AS, Choat JH (2003) Limited functional redundancy in high diversity systems: resilience and ecosystem function on coral reefs. Ecol Lett 6:281-285

Bellwood DR, Hughes TP, Hoey AS (2006) Sleeping functional group drives coral reef recovery. Curr Biol 16:2434-2439

Bennett S, Verges A, Bellwood DR (2010) Branching coral as a macroalgal refuge in a marginal coral reef system. Coral Reefs 29:471-480

Bonaldo RM, Bellwood DR (2008) Size-dependent variation in the functional role of the parrotfish Scarus rivulatus on the Great Barrier Reef, Australia. Mar Ecol Prog Ser 360:237-244

Bonaldo RM, Krajewski JP, Sazima C, Sazima I (2006) Foraging activity and resource use by three parrotfish species at Fernando de Noronha Archipelago, tropical West Atlantic. Mar Biol 149:423-433

Bonaldo RM, Krajewski JP, Sazima C, Sazima I (2007) Dentition damage in parrotfishes feeding on hard surfaces at Fernando de Noronha Archipelago, southwest Atlantic Ocean. Mar Ecol Prog Ser 342:249-254

Bouchon-Navaro Y, Harmelin-Vivien M (1981) Quantitative distribution of herbivorous reef fishes in the Gulf of Aqaba (Red Sea). Mar Biol 63:79-86

Bruggemann JH, Kuyper MWM, Breeman AM (1994a) Comparative analysis of foraging and habitat use by the sympatric Caribbean parrotfish Scarus vetula and Sparisoma viride (Scaridae). Mar Ecol Prog Ser 112:51-66

Bruggemann JH, van Oppen MJH, Breeman AM (1994b) Foraging by the stoplight parrotfish Sparisoma viride. I. Food selection in different socially, determined habitats. Mar Ecol Prog Ser 106:41-55

Bruggemann JH, Begeman J, Bosma EM, Verburg P, Breeman AM (1994c) Foraging by the stoplight parrotfish Sparisoma viride. II. Intake and assimilation of food, protein and energy. Mar Ecol Prog Ser 106:57-71

Burkepile DE, Hay ME (2008) Herbivore species richness and feeding complementarity affect community structure and function on a coral reef. Proc Natl Acad Sci USA 105:16201-16206

Burkepile DE, Hay ME (2009) Nutrient versus herbivore control of macroalgal community development and coral growth on a Caribbean reef. Mar Ecol Prog Ser 389:71-84

Caragnano A, Colombo F, Rodondi G, Basso D (2009) 3-D distribution of nongeniculate corallinales: a case study from a reef crest of South Sinai (Red Sea, Egypt). Coral Reefs 28: $881-891$

Carpenter RC (1985) Relationships between primary production and irradiance in coral reef algal communities. Limnol Oceanogr 30:784-793

Chen LS (2002) Post-settlement diet shift of Chlorurus sordidus and Scarus schlegeli (Pisces : Scaridae). Zool Stud 41:47-58

Choat JH (1991) The biology of herbivorous fishes on coral reefs. In: Sale PF (ed) The ecology of fishes on coral reefs. Academic Press, San Diego, pp 120-155

Choat JH, Clements KD, Robbins W (2002) The trophic status of herbivorous fishes on coral reefs 1: Dietary analyses. Mar Biol (Berl) 140:613-623

Clarke KR, Warwick RM (2001) Change in marine communities: an approach to statistical analysis and interpretation, 2nd edn. PRIMER-E, Plymouth

Clifton KE (1995) Asynchronous food availability on neighboring Caribbean coral reefs determines seasonal patterns of growth and reproduction for the herbivorous parrotfish Scarus iserti. Mar Ecol Prog Ser 116:39-46

Connell SD, Jones GP (1991) The influence of habitat complexity on postrecruitment processes in a temperate reef fish population. J Exp Mar Biol Ecol 151:271-294 
Crossman DJ, Choat JH, Clements KD, Hardy T, McConochie J (2001) Detritus as food for grazing fishes on coral reefs. Limnol Oceanogr 46:1596-1605

Crossman DJ, Choat JH, Clements KD (2005) Nutritional ecology of nominally herbivorous fishes on coral reefs. Mar Ecol Prog Ser 296:129-142

Diaz-Pulido G, Garzon-Ferreira J (2002) Seasonality in algal assemblages on upwelling-influenced coral reefs in the Colombian Caribbean. Bot Mar 45:284-292

Edwards FJ (1987) Climate and oceanography. In: Edwards AJ, Head MS (eds) Key environments: Red Sea. Pergamon, Oxford, pp 45-69

Fox RJ, Bellwood DR (2007) Quantifying herbivory across a coral reef depth gradient. Mar Ecol Prog Ser 339:49-59

Fox RJ, Bellwood DR (2008) Remote video bioassays reveal the potential feeding impact of the rabbitfish Siganus canaliculatus (f : Siganidae) on an inner-shelf reef of the Great Barrier Reef. Coral Reefs 27:605-615

Gunnarsson K, Ingolfsson A (1995) Seasonal changes in the abundance of intertidal algae in southwestern Iceland. Bot Mar 38:69-77

Hackney JM, Carpenter RC, Adey WH (1989) Characteristic adaptations to grazing among algal turfs on a Caribbean coral reef. Phycologia 28:109-119

Hatcher BG (1997) Coral reef ecosystems: How much greater is the whole than the sum of the parts? Coral Reefs 16:S77-S91

Hatcher BG, Larkum AWD (1983) An experimental analysis of factors controlling the standing crop of the epilithic algal community on a coral reef. J Exp Mar Biol Ecol 69:61-84

Hay ME, Colburn T, Downing D (1983) Spatial and temporal patterns in herbivory on a Caribbean fringing reef the effects on plant distribution. Oecologia 58:299-308

Hoey AS, Bellwood DR (2008) Cross-shelf variation in the role of parrotfishes on the Great Barrier Reef. Coral Reefs 27:37-47

Hurlbert SH (1978) The measurement of niche overlap and some relatives. Ecology 59:67-77

Klumpp DW, McKinnon AD (1989) Temporal and spatial patterns in primary production of a coral-reef epilithic algal community. J Exp Mar Biol Ecol 131:1-22

Klumpp DW, McKinnon AD (1992) Community structure, biomass and productivity of epilithic algal communities on the Great Barrier Reef: Dynamics at different spatial scales. Mar Ecol Prog Ser 86:77-89

Klumpp DW, Polunin NVC (1990) Algal production, grazers and habitat partitioning on a coral reef: positive correlation between grazing rate and food availability. In: Barnes M, Gibson RN (eds) Trophic relationships in the marine environment. Aberdeen University Press, Aberdeen, pp 372-388

Lechowicz MJ (1982) The sampling characteristics of electivity indexes. Oecologia 52:22-30

Ledlie MH, Graham NAJ, Bythell JC, Wilson SK, Jennings S, Polunin NVC, Hardcastle J (2007) Phase shifts and the role of herbivory in the resilience of coral reefs. Coral Reefs 26: 641-653

Lefevre CD, Bellwood DR (2010) Seasonality and dynamics in coral reef macroalgae: variation in condition and susceptibility to herbivory. Mar Biol 157:955-965

Lokrantz J, Nystrom M, Thyresson M, Johansson C (2008) The nonlinear relationship between body size and function in parrotfishes. Coral Reefs 27:967-974
Mantyka CS, Bellwood DR (2007) Macroalgal grazing selectivity among herbivorous coral reef fishes. Mar Ecol Prog Ser 352: 177-185

McClanahan TR, Hendrick V, Rodrigues M, Polunin NV (1999) Varying responses of herbivorous and invertebrate-feeding fishes to macroalgal reduction on a coral reef. Coral Reefs 18:195-203

McClanahan TR, Sala E, Stickels P, Cokos B, Baker A, Starger C, Jones S (2003) Interaction between nutrients and herbivory in controlling algal communities and coral condition on Glover's Reef, Belize. Mar Ecol Prog Ser 261:135-147

Mumby PJ, Hastings A, Edwards HJ (2007) Thresholds and the resilience of Caribbean coral reefs. Nature 450:98-101

Murray SN, Horn MH (1989) Seasonal dynamics of macrophyte populations from an eastern north Pacific rocky-intertidal habitat. Bot Mar 32:457-473

Polunin NVC, Klumpp DW (1989) Ecological correlates of foraging periodicity in herbivorous reef fishes of the Coral Sea. J Exp Mar Biol Ecol 126:1-20

Purcell SW, Bellwood DR (2001) Spatial patterns of epilithic algal and detrital resources on a windward coral reef. Coral Reefs 20:117-125

Randall JE (1961) Overgrazing of algae by herbivorous marine fishes. Ecology 42:812

Randall JE, Ormond RFG (1978) On the Red Sea parrotfishes of Forsskal, Scarus psittacus and S. ferrugineus. Zool J Linn Soc 63:239-248

Russ GR (1984) Distribution and abundance of herbivorous grazing fishes in the central Great Barrier Reef. I. Levels of variability across entire continental shelf. Mar Ecol Prog Ser 20:23-34

Russ GR (2003) Grazer biomass correlates more strongly with production than with biomass of algal turfs on a coral reef. Coral Reefs 22:63-67

Russ GR, McCook LJ (1999) Potential effects of a cyclone on benthic algal production and yield to grazers on coral reefs across the central Great Barrier Reef. J Exp Mar Biol Ecol 235:237-254

Smith EP (1982) Niche breadth, resource availability, and inference. Ecology 63:1675-1681

Sotka EE, Hay ME (2009) Effects of herbivores, nutrient enrichment, and their interactions on macroalgal proliferation and coral growth. Coral Reefs 28:555-568

Tribollet A, Langdon C, Golubic S, Atkinson M (2006) Endolithic microflora are major primary producers in dead carbonate substrates of Hawaiian coral reefs. J Phycol 42:292-303

Wilson S (2002) Nutritional value of detritus and algae in blenny territories on the Great Barrier Reef. J Exp Mar Biol Ecol 271:155-169

Wilson S, Burns K, Codi S (2001) Identifying sources of organic matter in sediments from a detritivorous coral reef fish territory. Org Geochem 32:1257-1269

Wilson SK, Bellwood DR, Choat JH, Furnas MJ (2003) Detritus in the epilithic algal matrix and its use by coral reef fishes. Oceanogr Mar Biol Annu Rev 41:279-309

Zekeria ZA, Videler JJ (2000) Correlation between the abundance of butterflyfishes and coral communities in the southern Red Sea. Proc 9th Int Coral Reef Symp I: 487-492

Zemke-White WL, Choat JH, Clements KD (2002) A re-evaluation of the diel feeding hypothesis for marine herbivorous fishes. Mar Biol (Berl) 141:571-579 